\title{
Management of Wounds with Exposed Bones or Tendons in Children by Vacuum-Assisted Closure Therapy: A Prospective Study
}

\author{
Altaf Rasool ${ }^{1}$ Sheikh Adil Bashir ${ }^{1}$ \\ Mir Yasir ${ }^{1} \quad$ Adil Hafeez Wani ${ }^{1}$ \\ ${ }^{1}$ Department of Plastic Surgery, Sher-i- Kashmir Institute of Medical \\ Sciences, Srinagar, Kashmir, India \\ ${ }^{2}$ Department of Surgery, Sher-i- Kashmir Institute of Medical \\ Sciences Srinagar, Kashmir, India \\ Indian J Plast Surg 2020;53:97-104
}

Prince Ajaz Ahmad ${ }^{2} \quad$ Akram Hussain Bijli ${ }^{1} \quad$ Umer Farooq Baba ${ }^{1}$

Address for correspondence Altaf Rasool, MCh Plastic Surgery, Sher-i- Kashmir Institute of Medical Sciences, Srinagar, Kashmir 190011, India (e-mail: altafrs।@gmail.com).

\begin{abstract}
Keywords

- vaccum-assisted closure

$-\mathrm{VAC}$

- exposed bone

- exposed tendon

Background The management of complex soft tissue defects with exposed bones/ tendons is always a challenging task for the surgeon and the problem becomes more pronounced when it comes to the management of these wounds in children. Though flap procedures are considered the standard for managing the complex soft tissue defects with exposed bones/tendons yet small blood vessels for anastomosis, long operative period, increased chances of perioperative thrombosis, and difficult perioperative management in children add to the difficulty in performing flap procedures in children. The vacuum-assisted closure (VAC) therapy has emerged as a novel modality for the management of the difficult wounds with added advantages, especially in children. Objective To evaluate the efficacy of VAC in the management of wounds with exposed bones/tendons in children.

Patients and Method Forty-six children of complex wounds with exposed bones/ tendons were included in the study from July 2016 to June 2018.

Results Out of 46 patients, 31 were male; the patients had a mean age of 8.4 years. Road traffic accident was the most common mode of injury (54\%), with most of the wounds located over extremities. The mean duration of VAC therapy was 12 days. More than $90 \%$ coverage of the exposed structure was seen in $89 \%$ of patients. The wounds were definitively managed by split-thickness skin graft in $89 \%$ of patients and flap cover in $6.5 \%$ of patients. The mean cost of the VAC therapy at our government run hospital was 187 Indian rupees per day. No significant major complications were seen during the treatment.

Conclusion VAC therapy is an efficient, safe, and cost-effective modality of treatment for the management of complex wounds in the pediatric population.
\end{abstract}

\section{Introduction}

The management of complex soft tissue defects with exposed bones/tendons is always a challenging task for the surgeon and the problem becomes more pronounced when it comes to the management of these wounds in children. The immature age, tragic incident of trauma, long hospital stay, and complex and invasive treatment required, all add to the psychological breakdown of the child. The overall situation demands a treatment modality that is effective, safe, relatively atraumatic, and less invasive so as to provide minimal discomfort, anxiety, and pain to the child while offering a standard care for the wound. ${ }^{1}$

Flap procedures are considered the standard for managing the complex soft tissue defects with exposed bones/tendons. But the morbidity and difficulties associated with flap
License terms

(요 (1) $\odot$ 
procedures make this modality less favorable in managing such wounds in children. Small blood vessels for anastomosis, long operative period, increased chances of perioperative thrombosis, and difficult perioperative management in children add to the difficulty in performing flap procedures in children.

The vacuum-assisted closure (VAC) therapy has emerged as a novel modality for the management of the difficult wounds. Although the literature is predominantly oriented toward the adults, there is enough scope to use this modality for managing the complex wounds in children. Good efficacy, relatively atraumatic nature, and less frequency of dressing changes make VAC a valuable option. It acts by macrodeformation, microdeformation, reduction of exudates, reduction of levels of bacteria, angiogenesis, and granulation tissue formation..$^{2-7}$ VAC therapy has been used in children in managing soft tissue defects with exposed bone/tendon/hardware to promote formation of granulation tissue. ${ }^{89}$ Abundance of such complex wounds in children in our society and keeping in view the simplicity of the procedure we decided to undertake such study in our hospital.

\section{Patients and Methods}

This was a prospective study conducted on 46 children in the Department of Plastic and Reconstructive Surgery from July 2016 to June 2018. Ethical approval was taken from the ethical committee of the hospital. In addition to the demographic data of the patients; mode of injury, site of injury, size of wound, and size of the exposed structure were noted. After thorough cleaning with saline, initial debridement and proper hemostasis under general anesthesia, the patients were subjected to VAC therapy. A wall-mounted vacuum creating device was used for the study ( - Fig. 1). Continuous mode of VAC therapy was used at a pressure between 100 and $125 \mathrm{~mm} \mathrm{Hg}$. We used two sheets of autoclaved sterilized locally available open cell polyurethane foam cut to fit the wound size and overlapping about $1 \mathrm{~cm}$ of surrounding skin and a fenestrated chest tube was put between the two layers and taken out of the foam by making a small hole in the outer foam layer. The whole dressing along with the chest tube was covered with transparent adhesive dressing (Iodrape) in such a way that vacuum seal was achieved. The children were attached to the vacuum device as soon as they were shifted to the ward. They were detached from the VAC in between only when they needed to go to washroom or the bed position needed to be changed for some reasons. VAC dressings were changed at a frequency of two to three times a week after adequate analgesia. The wounds of the patients were evaluated by serial measurements and photographs of the wound to determine the contracture of the wound and coverage of exposed bone/tendon by healthy granulation tissue at each dressing change. Wounds that got covered with $>90 \%$ granulation tissue by VAC therapy were considered successful; those covered between 50 and $90 \%$ were considered satisfactory, and those wounds in which $<50 \%$ granulation covered the wound were considered failure. End point of the therapy was selected either when the wound was completely covered

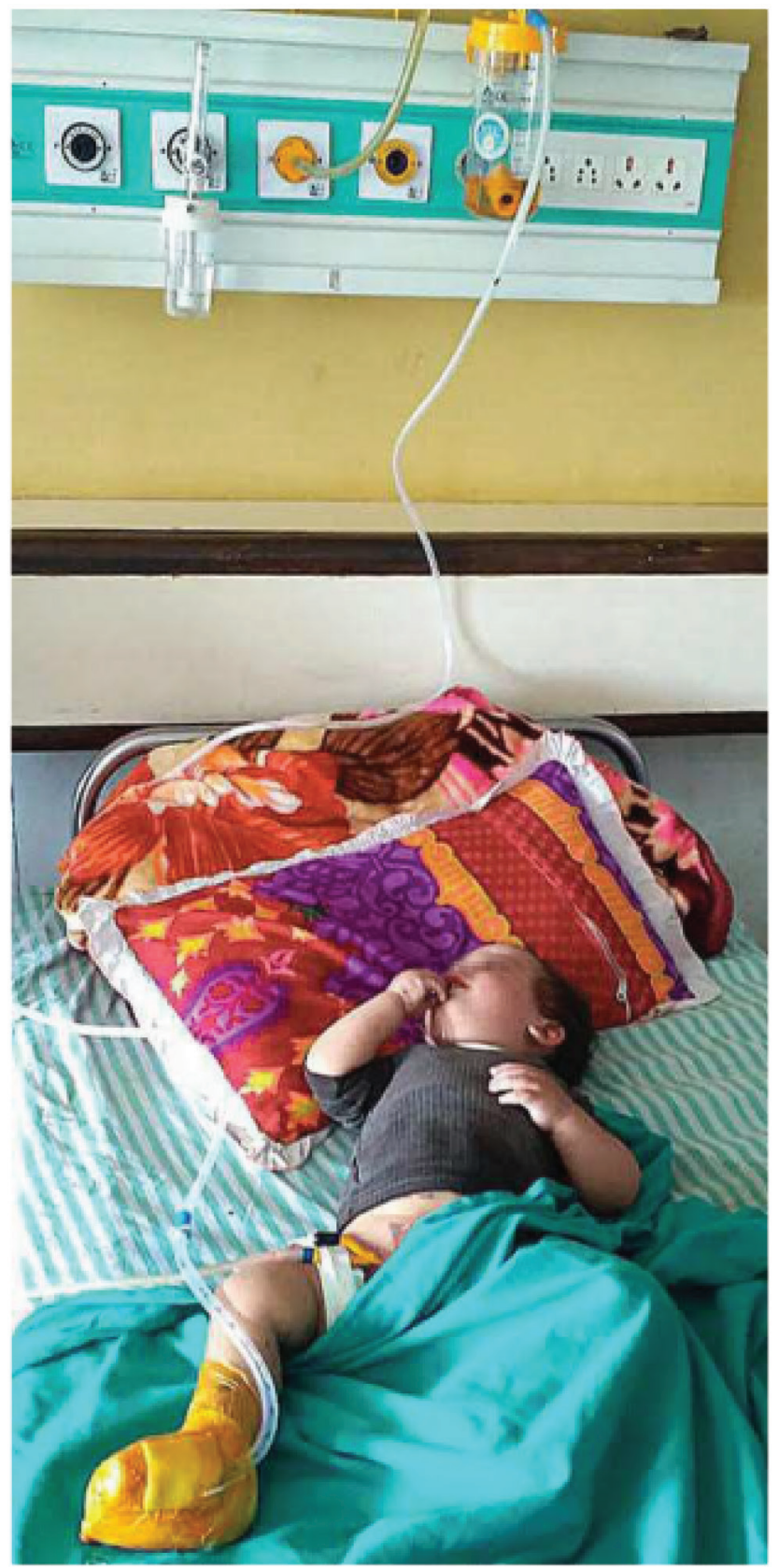

Fig. 1 Wall-mounted vacuum-creating device used in our study.

by healthy granulation tissue or if there was no response to three consecutive VAC dressings. Patients were later managed with split-thickness skin graft (STSG)/flap covers and followed postoperatively on outpatient basis.

\section{Results}

Forty-six patients (up to age 15 years) were subjected to the VAC therapy (-Table $\mathbf{1}$ ). Mean age of the patients was 8.4 years with a male: female ratio of 2:1. Road traffic accident was the commonest mode of injury (48\%), followed by machine injury (24\%) and fall from height (11\%). Majority of patients sustained injuries to lower limb (82.6\%) followed by upper limb (13\%) and scalp (4.3\%). Twenty-four patients had

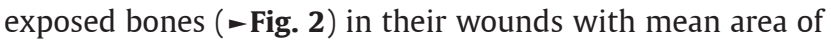


Table 1 Showing details of the patients with regard to etiology, size of exposed structures and duration of vacuum-assisted closure (VAC) therapy required

\begin{tabular}{|c|c|c|c|c|}
\hline S.NO & Etiology & Area of bone exposed & Length of tendon exposed & Duration of VAC \\
\hline 1 & RTA & $<10 \mathrm{~cm}^{2}$ & Nil & $10-15$ days \\
\hline 2 & RTA & $<10 \mathrm{~cm}^{2}$ & Nil & $>15$ days \\
\hline 3 & RTA & $10-30 \mathrm{~cm}^{2}$ & Upto $5 \mathrm{~cm}$ & $>15$ days \\
\hline 4 & RTA & $<10 \mathrm{~cm}^{2}$ & Upto $5 \mathrm{~cm}$ & $>15$ days \\
\hline 5 & RTA & $<10 \mathrm{~cm}^{2}$ & Nil & $10-15$ days \\
\hline 6 & RTA & $<10 \mathrm{~cm}^{2}$ & Upto $5 \mathrm{~cm}$ & 10-15 days \\
\hline 7 & RTA & Nil & Upto $5 \mathrm{~cm}$ & $<10$ days \\
\hline 8 & RTA & $>30 \mathrm{~cm}^{2}$ & Nil & $>15$ days \\
\hline 9 & RTA & Nil & Upto $5 \mathrm{~cm}$ & $10-15$ days \\
\hline 10 & RTA & $<10 \mathrm{~cm}^{2}$ & $>5 \mathrm{~cm}$ & $10-15$ days \\
\hline 11 & $\mathrm{FFH}$ & $<10 \mathrm{~cm}^{2}$ & Upto $5 \mathrm{~cm}$ & 10-15 days \\
\hline 12 & RTA & $<10 \mathrm{~cm}^{2}$ & Upto $5 \mathrm{~cm}$ & $>15$ days \\
\hline 13 & RTA & $<10 \mathrm{~cm}^{2}$ & Nil & $10-15$ days \\
\hline 14 & Machine injury & $<10 \mathrm{~cm}^{2}$ & $\mathrm{Nil}$ & 10-15 days \\
\hline 15 & RTA & $<10 \mathrm{~cm}^{2}$ & Nil & $10-15$ days \\
\hline 16 & RTA & $<10 \mathrm{~cm}^{2}$ & Nil & $10-15$ days \\
\hline 17 & Machine injury & $>30 \mathrm{~cm}^{2}$ & $\mathrm{Nil}$ & $>15$ days \\
\hline 18 & $\mathrm{FFH}$ & $<10 \mathrm{~cm}^{2}$ & $\mathrm{Nil}$ & 10-15 days \\
\hline 19 & RTA & $10-30 \mathrm{~cm}^{2}$ & Nil & $10-15$ days \\
\hline 20 & Animal Attack & $>30 \mathrm{~cm}^{2}$ & $\mathrm{Nil}$ & $10-15$ days \\
\hline 21 & $\mathrm{FFH}$ & $<10 \mathrm{~cm}^{2}$ & Upto $5 \mathrm{~cm}$ & $10-15$ days \\
\hline 22 & RTA & $<10 \mathrm{~cm}^{2}$ & Upto $5 \mathrm{~cm}$ & 10-15 days \\
\hline 23 & RTA & $\mathrm{Nil}$ & $\mathrm{Nil}$ & 10-15 days \\
\hline 24 & RTA & $10-30 \mathrm{~cm}^{2}$ & Nil & $>15$ days \\
\hline 25 & RTA & $10-30 \mathrm{~cm}^{2}$ & $\mathrm{Nil}$ & $>15$ days \\
\hline 26 & $\mathrm{FFH}$ & Nil & $>5 \mathrm{~cm}$ & $>15$ days \\
\hline 27 & Machine injury & $<10 \mathrm{~cm}^{2}$ & $\mathrm{Nil}$ & $>15$ days \\
\hline 28 & Machine injury & $\mathrm{Nil}$ & Upto $5 \mathrm{~cm}$ & $>15$ days \\
\hline 29 & Machine injury & $\mathrm{Nil}$ & Upto $5 \mathrm{~cm}$ & $>15$ days \\
\hline 30 & Machine injury & Nil & Nil & >15 days \\
\hline 31 & Machine injury & $\mathrm{Nil}$ & Upto $5 \mathrm{~cm}$ & 10-15 days \\
\hline 32 & RTA & Nil & Nil & $10-15$ days \\
\hline 33 & RTA & $<10 \mathrm{~cm}^{2}$ & $\mathrm{Nil}$ & $>15$ days \\
\hline 34 & Machine injury & $\mathrm{Nil}$ & $>5 \mathrm{~cm}$ & $>15$ days \\
\hline 35 & Machine injury & $\mathrm{Nil}$ & $>5 \mathrm{~cm}$ & $>15$ days \\
\hline 36 & Machine injury & $\mathrm{Nil}$ & Upto $5 \mathrm{~cm}$ & 10-15 days \\
\hline 37 & Machine injury & $10-30 \mathrm{~cm}^{2}$ & $\mathrm{Nil}$ & $>15$ days \\
\hline 38 & RTA & $\mathrm{Nil}$ & $>5 \mathrm{~cm}$ & $>15$ days \\
\hline 39 & Burn & $\mathrm{Nil}$ & Upto $5 \mathrm{~cm}$ & $10-15$ days \\
\hline 40 & RTA & $>30 \mathrm{~cm}^{2}$ & $\mathrm{Nil}$ & $>15$ days \\
\hline 41 & Burn & $\mathrm{Nil}$ & Upto $5 \mathrm{~cm}$ & $10-15$ days \\
\hline 42 & FAI & $<10 \mathrm{~cm}^{2}$ & $\mathrm{Nil}$ & 10-15 days \\
\hline 43 & Machine injury & $\mathrm{Nil}$ & Upto $5 \mathrm{~cm}$ & $>15$ days \\
\hline 44 & $\mathrm{FFH}$ & $<10 \mathrm{~cm}^{2}$ & Nil & $10-15$ days \\
\hline 45 & RTA & $<10 \mathrm{~cm}^{2}$ & Nil & 10-15 days \\
\hline 46 & RTA & $<10 \mathrm{~cm}^{2}$ & Nil & $10-15$ days \\
\hline
\end{tabular}



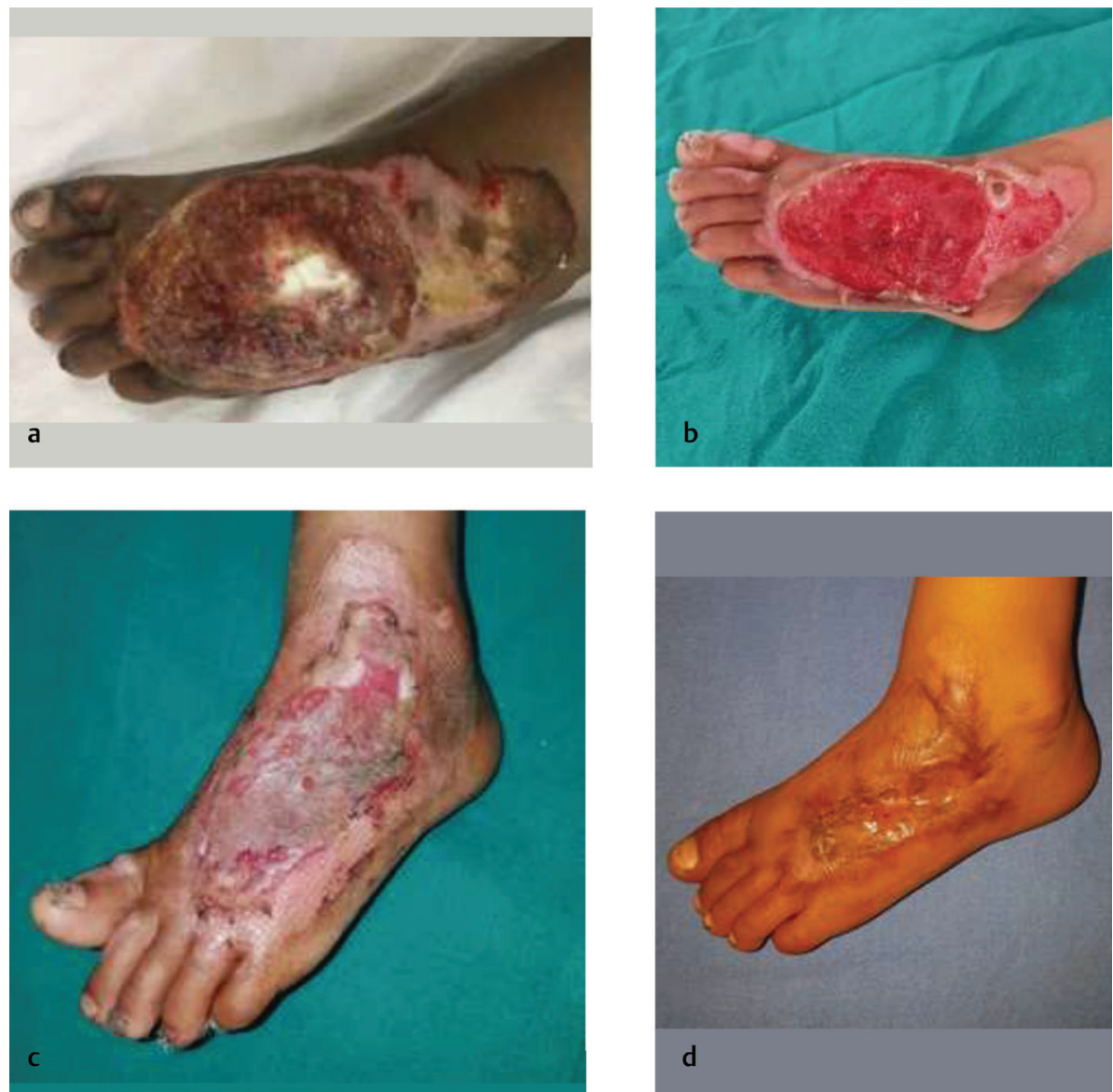

Fig. 2 (a) Patient with exposed bone over anterior aspect of foot. (b) Exposed bone covered by healthy granulation tissue after 18 days of vacuum-assisted closure therapy. (c) Wound after 2 weeks post split-thickness skin graft. (d) Well-settled graft after 6 months.

$8 \mathrm{~cm}^{2}$ (range 4-34 $\mathrm{cm}^{2}$ ). Exposed tendon (-Fig. 3) was present in 15 cases with mean exposed tendon length of $4 \mathrm{~cm}$ (range 1-7 cm). The average number of VAC dressings applied was 4.5 (range 2-9). The mean duration of VAC therapy in our study was 12 days with a range of 6 to 27 days. In our study patients, more than $90 \%$ coverage of the exposed structure was seen in $89 \%$ of subjects and in four patients only $<50 \%$ coverage of the exposed structure was seen. Eighty-nine percent of patients were managed by STSG, 6.5\% patients required flap coverage and $4.3 \%$ patients required both STSG and flap coverage for the management of their wounds. No significant complications were seen in the patients. Minor episodes of pain, periwound maceration, and bleeding were seen during the treatment.

The mean total cost of the therapy was 2250 Indian rupees (32 USD) with a mean per day cost of 187 Indian rupees (2.6 USD).

\section{Discussion}

VAC technique has evolved as a powerful treatment modality for the management of complex soft tissue defects. The rapid formation of the healthy granulation tissue is essential for the management of these wounds. Flap coverage is considered standard for the management of wounds with exposed bones/tendons but it is associated with difficulty and morbidity when compared with VAC. Keeping in view the additional difficulties involved in the flap procedures in children, VAC becomes an attractive and a promising modality for managing wounds with exposed bone/tendons in children and hence is the core theme of this study.

Most of the wounds in our study subjects were on extremities (lower limb > upper limb). Foot was the most common site followed by leg and forearm. Various other studies have also observed the extremities as the commonest site of injury. ${ }^{10-12}$

Majority of the patients in our series had exposed bones (52\%) with a mean area of $8 \mathrm{~cm}^{2}$ followed by exposed tendons $(32.5 \%)$ with a mean exposed tendon length of $4 \mathrm{~cm}$. However, $15 \%$ of patients had both exposed bone as well as tendons (-Figs. 4 and $\mathbf{5}$ ). Similar results were also observed by Mullner et $\mathrm{al}^{10}$ and Repta et $\mathrm{al}{ }^{13}$ while treating patients of exposed bones and tendons with VAC therapy.

The average number of VAC dressings needed per patient in our study was 4.5. Though our results coincide with those seen by Eltayeb et $\mathrm{al}^{14}$ and Lee et $\mathrm{al}^{15}{ }^{15}$ most other studies either needed more ${ }^{10,12}$ or they needed less ${ }^{9,16}$ number of VAC dressings to cover the wounds by healthy granulation tissue than in our study. This variation in the number of VAC dressings needed can be explained by varying clinicopathological factors involved in the wound healing including infection, underlying comorbidities, technique of VAC used, pressures used in VAC, and differences in wound size. 

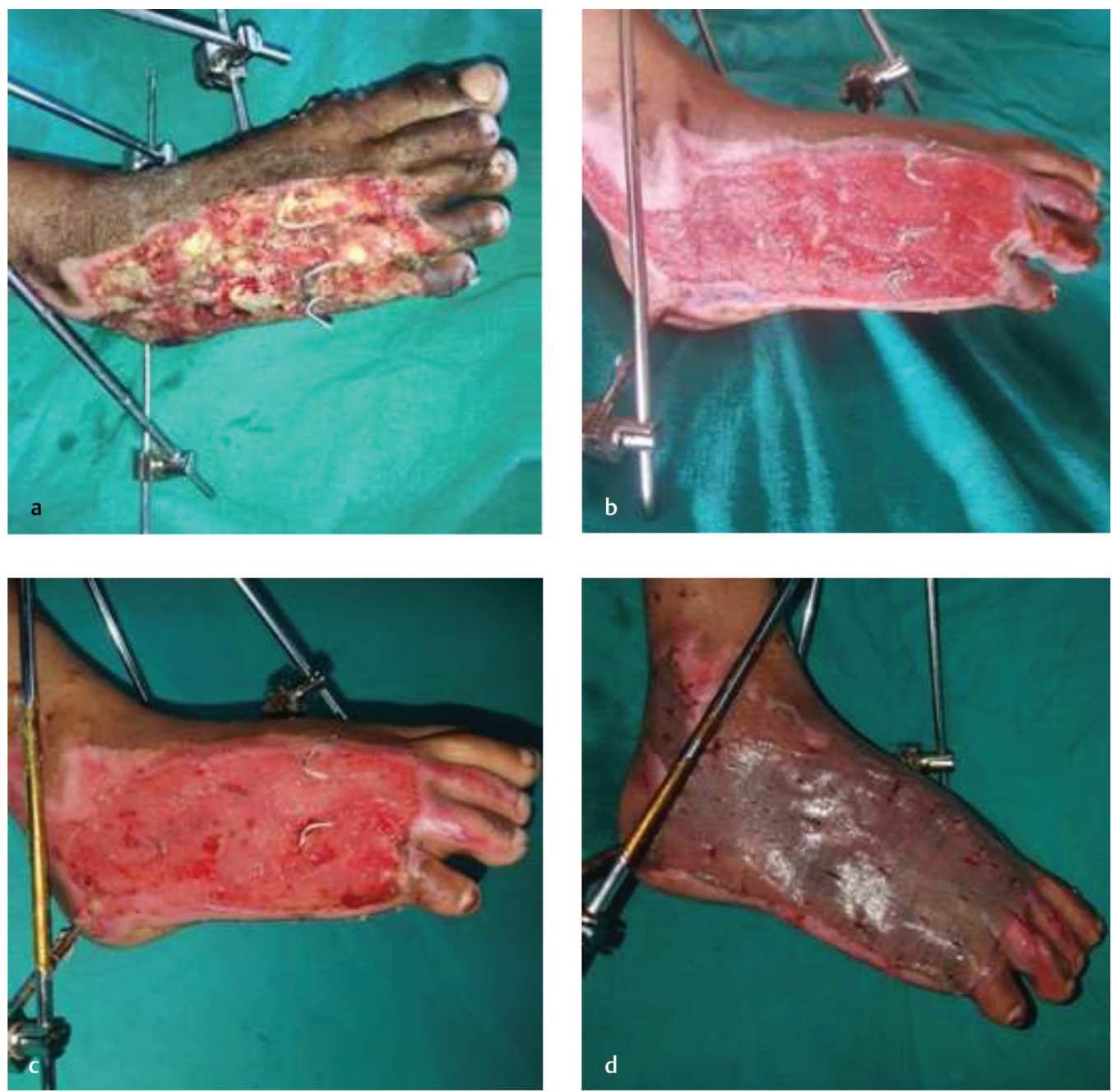

Fig. 3 (a) Post-traumatic wound with exposed bones/tendons over the lateral aspect of foot. (b) Post-traumatic wound with exposed bones/ tendons over the lateral aspect of foot. (c) Wound fully covered with granulation tissue after 17 days of vacuum-assisted closure therapy. (d) Wound covered successfully with split-thickness skin graft.

The mean duration of completion of successful VAC therapy in our study was 12 days. Eltayeb et al ${ }^{14}$ also observed a mean duration of successful VAC as 12 days in their patients, but some authors have reported relatively higher average number of days needed to grow healthy granulations. ${ }^{10,17}$ Baharestani et al, however, could manage the complex soft tissue wounds in children by VAC therapy with a mean duration of 10 days. ${ }^{18}$ This variation in mean duration of therapy required is again probably explained by different clinicopathological factors involved in wound healing.

Successful VAC therapy was seen in $89 \%$ of subjects in our study. Patients whose bone exposure was more than $30 \mathrm{~cm}^{2}$ failed to respond to the VAC therapy. Mullner et al reported that $100 \%$ patients in their series were covered by healthy granulation tissue ${ }^{10}$ while Lee et $\mathrm{al}^{15}$ and Baharestani et al ${ }^{18}$ reported that more than $90 \%$ were successfully treated. However, results are not always as favorable as stated earlier, because Caniano et al could cover only $57 \%$ of wounds with STSG after VAC therapy. ${ }^{19}$

Pain, especially at the time of dressing change, was experienced by $\sim 80 \%$ of the patients that was easily managed with oral/intravenous analgesics. Minor periwound maceration and minor episodes of the bleeding from wound were seen in $\sim 30 \%$ and $19 \%$ of patients, respectively. Bleeding was mainly attributed to the adherence of the foam dressing to the wound bed and was significantly decreased when the wounds were irrigated by saline via suction tubing before removal of the foam dressing. None of the complications mentioned earlier led to the discontinuation of VAC therapy in the study patients. There was no incident of graft or flap loss in the study subjects. Similar minor complications were seen in other studies., 8,9,20

The average total cost of the VAC therapy in our study was 1,050 Indian rupees, which amounts to a mean of $\sim 15$ USD. In terms of cost per day it amounts to 87.5 Indian rupees or 1.25 USD. This cost applies only to VAC therapy excluding hospital charges. Rupees 100/day was the hospital charges for all the patients, thus the mean total cost of the therapy was 2250 Indian rupees (32 USD) with a mean per day cost of 187 Indian rupees (2.6 USD). Kolios et $\mathrm{al}^{21}$ reported an average total cost of VAC therapy in their patients as 3,266 USD while Chaput et $\mathrm{al}^{22}$ and Braakenburg et al ${ }^{23}$ reported 

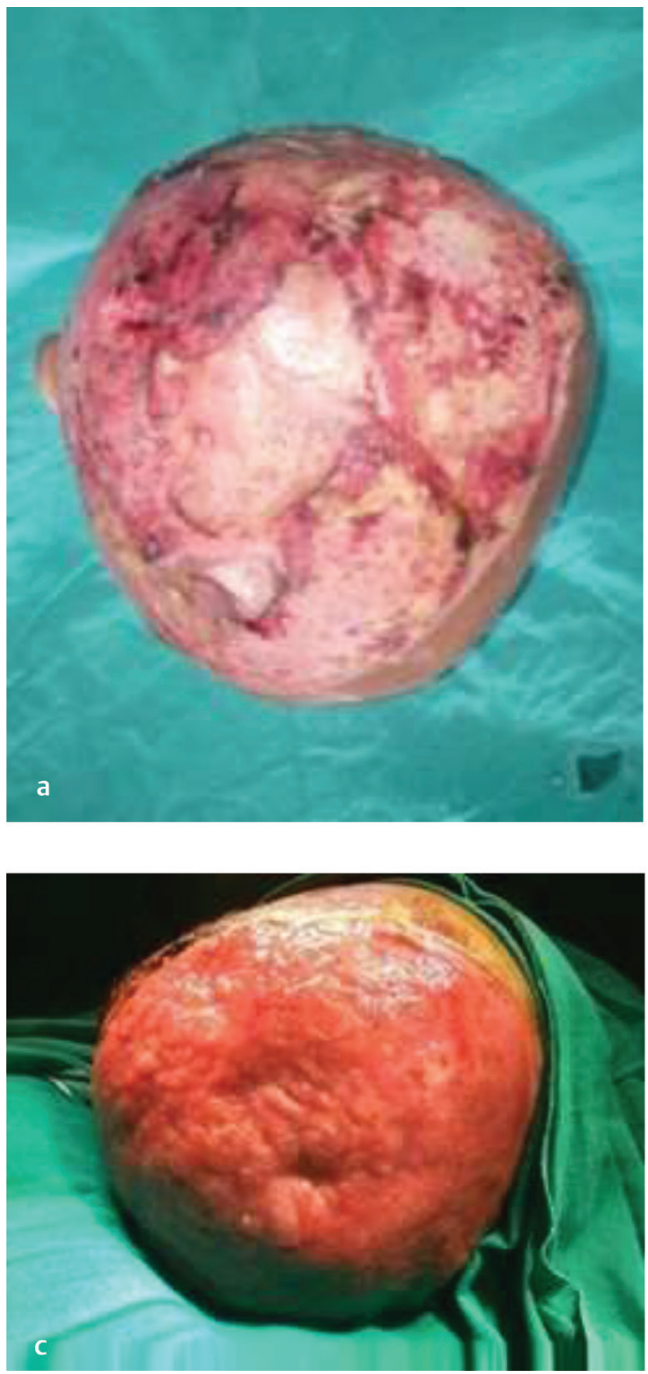
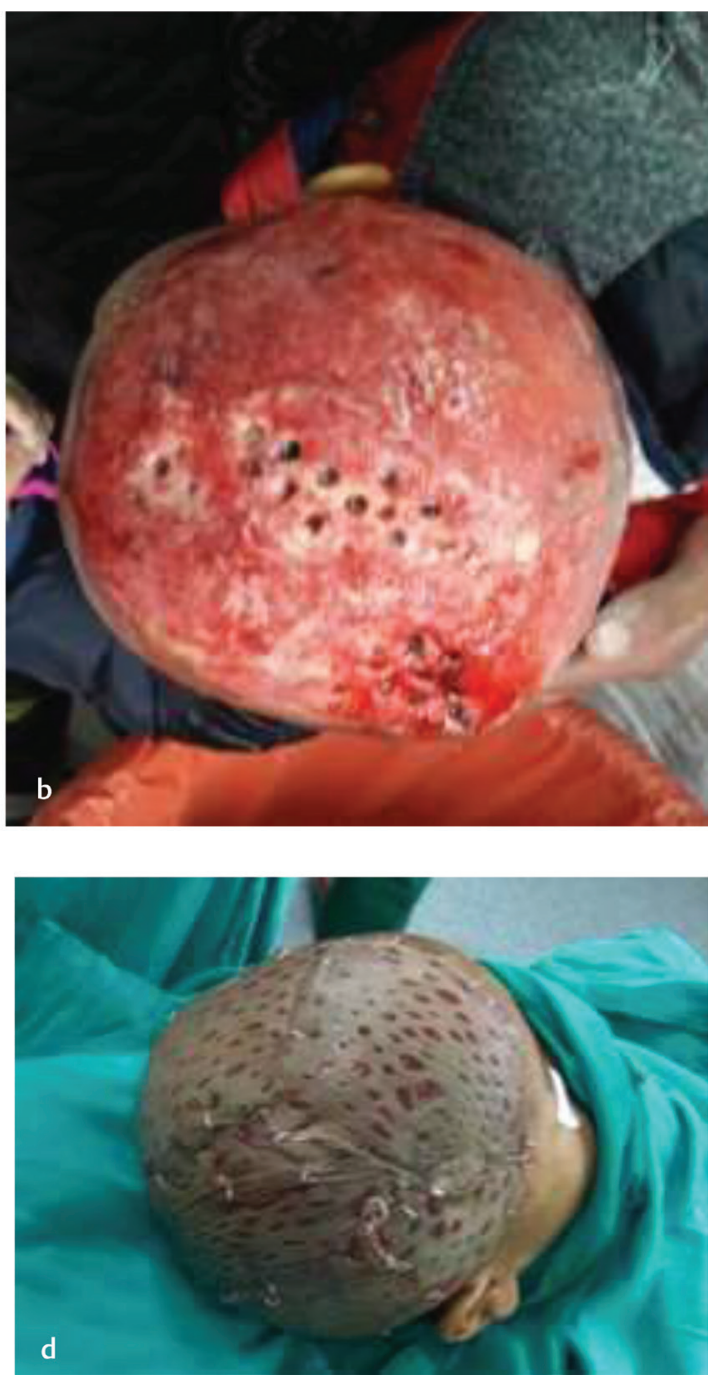

Fig. 4 8-year-old child with raw area over scalp with exposed bone. (b) Wound showing coverage of exposed bone (Burr holes in situ). (c) Wound completely covered with healthy granulation tissue after 20 days of VAC therapy. (d) Wound managed definitively with split-thickness skin graft.

an average cost of 15 USD and 24 Euros per day, respectively. The disparity in the average cost per day in our study as compared with others is explained by the fact that ours is a government hospital-based study and the patient had to buy only the adhesive drape used in the VAC therapy. Rest of the material including the foam, tubing and labor was provided by the hospital. We used a wall-mounted vacuum-creating apparatus for the study, which is also the property of the hospital.

VAC therapy is even considered to be the cost effective when compared with the conventional treatment. Moues et $\mathrm{al}^{24}$ reported that the cost of VAC therapy was higher than the conventional therapy (520 USD vs. 18 USD) when only material cost was taken into consideration but when the hospital and nursing charges were included (2,252 USD vs. 3,206 USD, respectively), the overall cost of treatment by VAC was less compared with the conventional dressing (2,810 USD for VAC vs. 3,225 USD for conventional therapy).
Finally, more clinical trials are needed to confirm the clinical evidence base needed for this powerful wound care technique especially in identifying the factors that determine incomplete response to the therapy. In addition, studies are also needed to see the long-term outcome of these patients especially with regard to wound break down, tendon gliding, contracture development, and joint function and thus to ascertain whether this form of treatment could serve as a sole treatment or any further definitive management is needed in these patients.

\section{Conclusion}

In conclusion, our study supports the VAC therapy as a relatively atraumatic technique to manage soft tissue defects in complex extremity wounds in pediatric patients. The VAC therapy proved to be an effective, safe, cost effective, easy to learn, and simple technique that managed the 

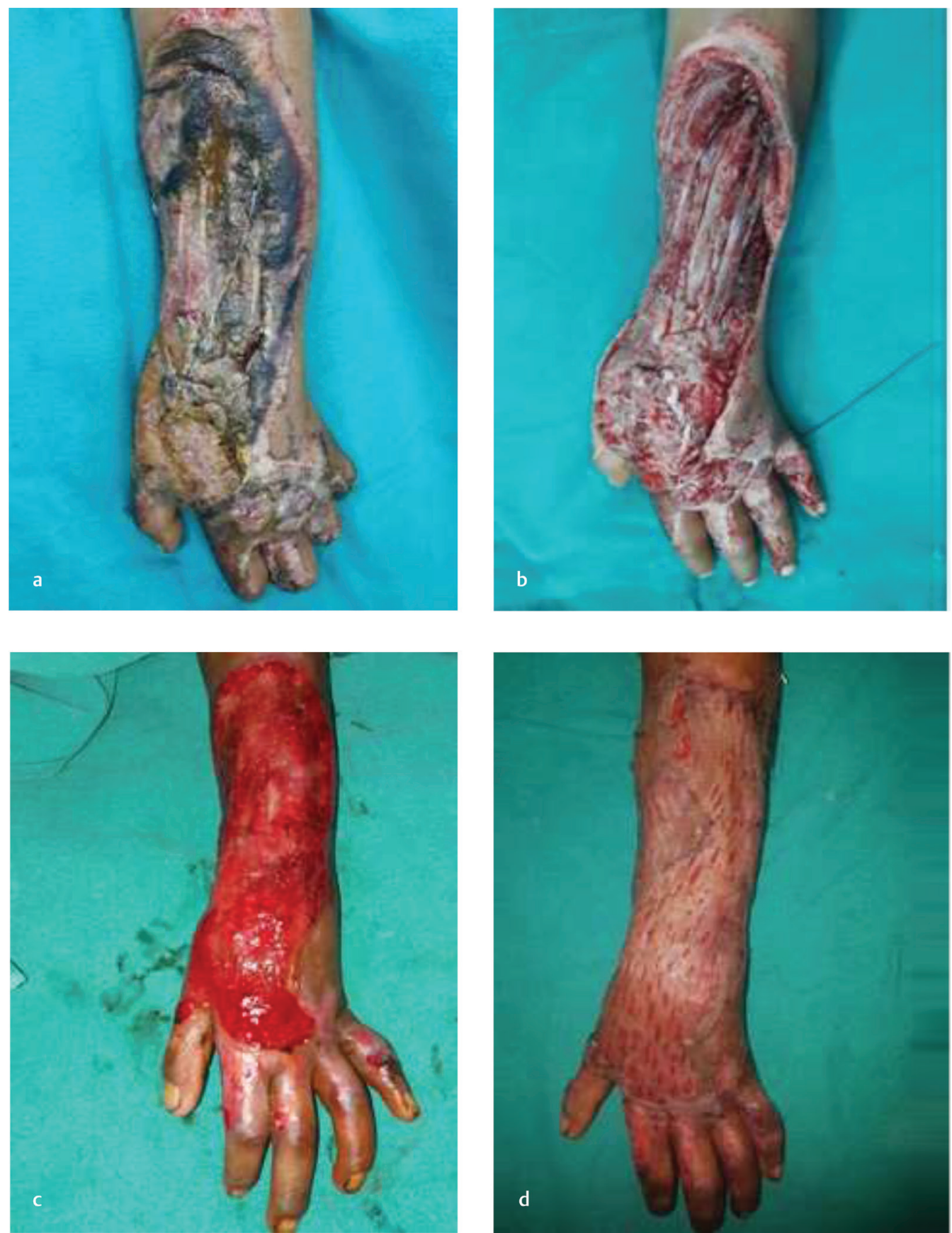

Fig. 5 Patient with post-traumatic compound defect over forearm. (b) Wound after debridement showing exposed bone/tendon. (c) Wound after 22 days of VAC therapy. (d) Wound managed definitively by split-thickness skin graft.

complex soft tissue defects in children without the morbidity and complications associated with flap procedures.

\section{Declaration of Patient Consent}

The authors certify that they have obtained all appropriate patient consent forms. In the form the patients have given their consent for their images and other clinical information to be reported in the journal. The patients understand that their names and initials will not be published and due efforts will be made to conceal their identity, but anonymity cannot be guaranteed.

\section{Note}

There is no financial or any other support from any of the organizations.

\section{Financial Support and Sponsorship}

Nil.

\section{Conflicts of Interest}

There are no conflicts of interest. 


\section{References}

1 Chariker ME, Gerstle TL, Morrison CS. An algorithmic approach to the use of gauze-based negative-pressure wound therapy as a bridge to closure in pediatric extremity trauma. Plast Reconstr Surg 2009;123(5):1510-1520

2 Fenn $\mathrm{CH}$, Butler PE. Abdominoplasty wound-healing complications: assisted closure using foam suction dressing. Br J Plast Surg 2001;54(4):348-351

3 Banwell PE, Téot L. Topical negative pressure (TNP): the evolution of a novel wound therapy. J Wound Care 2003;12(1):22-28

4 Orgill DP, Manders EK, Sumpio BE, Lee RC, Attinger CE. Mechanism of action of vacuum assisted closure: more to learn. J Surg 2009;146:40-51

5 Wiegand C, White R. Microdeformation in wound healing. Wound Repair Regen 2013;21(6):793-799

6 Morykwas MJ, Argenta LC, Shelton-Brown EI. McGuirt W. Vacuum-assisted closure: a new method for wound control and treatment: animal studies and basic foundation. Ann Plast Surg 1997;38(6):553-562

7 Ilizarov GA. The tension-stress effect on the genesis and growth of tissues. Part I. The influence of stability of fixation and soft-tissue preservation. Clin Orthop Relat Res 1989; ( 238):249-281

8 Mooney JF, III, Argenta LC, Marks MW, Morykwas MJ, DeFranzo AJ. Treatment of soft tissue defects in pediatric patients using the V.A.C. system. Clin Orthop Relat Res 2000; ( 376):26-31

9 DeFranzo AJL, Argenta LC, Marks MW, et al. The use of vacuum-assisted closure therapy for the treatment of lowerextremity wounds with exposed bone. Plast Reconstr Surg 2001;108(5):1184-1191

10 Mullner T, Mrkonjic L, Kwasny O, Vecsie V. The use of negative pressure to promote the healing of tissue defects: a clinical trial using the vacuum sealing technique. Br J Plast Surg 1997;50:194-199

11 DeFranzo AJ, Marks MW, Argenta LC, Genecov DG. Vacuum-assisted closure for the treatment of degloving injuries. Plast Reconstr Surg 1999;104(7):2145-2148

12 Helgeson MD, Potter BK, Evans KN, Shawen SB. Bioartificial dermal substitute: a preliminary report on its use for the management of complex combat-related soft tissue wounds. J Orthop Trauma 2007;21(6):394-399

13 Repta R, Ford R, Hoberman L, Rechner B. The use of negative-pressure therapy and skin grafting in the treatment of soft-tissue defects over the Achilles tendon. Ann Plast Surg 2005;55(4):367-370

14 Eltayeb H, Kassem R. Negative pressure wound therapy in pediatric extremity trauma: a single-institute experience. Egypt J Surg 2017;36:260-264

15 Lee HJ, Kim JW, Oh CW, et al. Negative pressure wound therapy for soft tissue injuries around the foot and ankle. J Orthop Surg Res 2009;4:14

16 Dedmond BT, Kortesis B, Punger K, et al. Subatmospheric pressure dressings in the temporary treatment of soft tissue injuries associated with type III open tibial shaft fractures in children. J Pediatr Orthop 2006;26:728-732

17 Kang GC, Por YC, Tan BK. In vivo tissue engineering over wounds with exposed bone and tendon: autologous dermal grafting and vacuum-assisted closure. Ann Plast Surg 2010;65(1):70-73

18 Baharestani MM. Use of negative pressure wound therapy in the treatment of neonatal and pediatric wounds: a retrospective examination of clinical outcomes. Ostomy Wound Manage 2007;53(6):75-85

19 Caniano DA, Ruth B, Teich S. Wound management with vacuum-assisted closure: experience in 51 pediatric patients. J Pediatr Surg 2005;40(1):128-132

20 Bütter A, Emran M, Al-Jazaeri A, Ouimet A. Vacuum-assisted closure for wound management in the pediatric population. J Pediatr Surg 2006;41(5):940-942

21 Kolios L, Kolios G, Beyersdorff M, et al. Cost analysis of topical negative pressure (TNP) therapy for traumatic acquired wounds. Ger Med Sci 2010;8:Doc13

22 Chaput B, Garrido I, Eburdery H, Grolleau JL, Chavoin JP. Lowcost negative-pressure wound therapy using wall vacuum: a 15 dollar by day alternative. Plast Reconstr Surg Glob Open 2015;3(6):e418

23 Braakenburg A, Obdeijn MC, Feitz R. van Rooij IA, van Griethuysen AJ, Klinkenbijl JH. The clinical efficacy and cost effectiveness of the vacuum-assisted closure technique in the management of acute and chronic wounds: a randomized controlled trial. Plast Reconstr Surg 2006;118(2):390-397

24 Mouës CM, van den Bemd GJ, Meerding WJ, Hovius SE. An economic evaluation of the use of TNP on full-thickness wounds. J Wound Care 2005;14(5):224-227 